\title{
Revisiting notions of sex trafficking and victims
}

\author{
Adriana Piscitelli \\ Center for Gender Studies PAGU, State University of Campinas
}

\section{Resumo}

Neste artigo analiso os processos migratórios e as experiências laborais de trabalhadoras sexuais brasileiras na Espanha. Baseando-me em pesquisa etnográfica realizada durante onze meses, em diferentes momentos entre Novembro de 2004 e Janeiro de 2012, em Barcelona, Madri, Bilbao e Granada, argumento que os significados concedidos ao trabalho sexual pelas entrevistadas divergem daqueles expressados nas noções sobre prostituição e tráfico internacional de pessoas presentes no debate público sobre essas problemáticas. As ações e percepções das trabalhadoras sexuais brasileiras entrevistadas desafiam protocolos nacionais e culturais nacionais e internacionais e também o "destino" para elas traçado no Brasil

Palavras-chave: tráfico internacional de pessoas com fins de exploração sexual, migração, trabalho sexual, vítimas

\begin{abstract}
This article examines the migratory processes and work experiences of Brazilian female sex workers active in Spain. It is based on ethnographic research conducted over eleven months, at different moments between November 2004 and January 2012, in Barcelona, Madrid, Bilbao and Granada. The principal argument is that the notions of prostitution and international human trafficking held by Brazilian sex workers clash with those found in the current public debate of these issues. Brazilian migrant sex workers' acts and beliefs defy political and cultural protocols on the national and international level, and fly in the face of the 'destiny' that Brazilian society laid out for these individuals.
\end{abstract}

Keywords: sex trafficking, migration, sex work, victims 


\title{
Revisiting notions of sex trafficking and victims'
}

\author{
Adriana Piscitelli \\ Center for Gender Studies PAGU, State University of Campinas
}

\section{Introduction}

Recent critical literature on trafficking in persons draws attention to the fact that the United Nations Office on Drugs and Crime (UNODC) portrayed Brazil in 2010 as one of the three countries that export the largest number of slaves to Europe, and highlights the inconsistencies of the data on which this assessment is based (Blanchette and da Silva, 2012). In the 2011 Trafficking in Persons Report, the United Nations reiterated the idea that Brazil was a significant source country for men, women, and children subjected to sex trafficking abroad, often in European countries (Departament of State, 2011).

These perceptions about trafficking involving Brazilian citizens were produced during the first decade of the $21^{\mathrm{st}}$ century. During those years, European destination countries, particularly Spain ${ }^{1}$, became a matter of serious concern to the Brazilian government and to NGOs. This concern was fed by the publications of multilateral supranational agencies, international police actions and anti-trafficking media campaigns undertaken by the Brazilian government, and NGOs (Grupo Davida 2005; Blanchette, 2008; Blanchette and Da Silva, 2012; Piscitelli 2008). Taking this public anxiety as my point of departure, I examine in this paper the migratory processes and work experiences of Brazilian female sex workers active in Spain, a nation that attracted significant numbers of Brazilian immigrant women².

\footnotetext{
1 Parts of a previous version of this article were published in Zheng, Tian Tian: "Sex Trafficking, Human Rights, and Social Justice.” Routledge, 192-215, 2010

2 The research that the present paper is based upon was made possible by post-doctoral research grants and aid from the following institutions: Fapesp, CAPES, CNPq and GEMMA (at the Universidad de Granada). I'd like to thank my interviewees, the workers at the Brazilian Consulates in Barcelona and Madrid and, in particular, Gelson Fonseca (the Consul General of Brazil in Spain in 2007/2008), Durval Ferraz, Dolores Juliano, Verena Stolcke, Isabel Holgado, Bea, Constancia, Carla, Justine, Cristina Garaizával, Lurdes Perramon, Beatriz Espejo, Elena, Estefanía Acién, Hermanas Oblatas y Adoratrices,
} 
My principal argument is that the notions of prostitution and international human trafficking held by Brazilian sex workers clash with those found in the current public debate of these issues. Simply put, Brazilian migrant sex workers' acts and beliefs defy political and cultural protocols on the national and international level, and fly in the face of the 'destiny' that Brazilian society lays out for these individuals.

Ethnography, the central methodology I used in my study, has been a powerful tool for unpacking a series of propagated suppositions regarding the migration of sex workers. I refer here to the prolonged insertion into a given field as a participant-observer, a situation in which direct observation is fundamental and in which intense interactions affect the material collected in "ethnographic interviews" (Pack 2006). My fieldwork was of fundamental importance for my comprehension of the perspectives expressed by my interviewees and of the different spaces in which agency operates during the migratory processes.

I conducted research over eleven months at different moments between November 2004 and January 2012 in Barcelona, Madrid, Bilbao and Granada. Simultaneously, I carried on parallel researches on the sex trafficking debate and actions in Brazil (Piscitelli, 2008; 2011). In Spain, my field work included direct observation in spaces where sexual services were offered, such as certain streets, apartments and clubs where I conducted in-depth interviews during my interviewees' breaks, and also in cafés, bars and in their homes ${ }^{3}$. I contacted some of my interviewees through NGOs that offer aid to sex workers and these initial contacts gained me access to other sex workers, their friends, colleagues and clients. In addition, I followed the paths of several of those interviewees over the years in different cities. ${ }^{4}$

Genera, Ambit Dona, Hetaira, Proyecto Carretera en Calella, Colectivo de Transexuales de Cataluña, Comisión Ciudadana Antisida de Biskaia, Asociación pro derechos Humanos de Andalucia and, especially, Laura Agustín and the other members of the on-line INDÚSTRIA DEL SEXO network for support, bibliographic material and contacts. I'd also like to thank the two anonymous reviewers of Vibrant for their helpful remarks.

3 I conducted in-depth interviews with 19 Brazilian women and five Brazilian transgendered individuals who offered sexual services for sale in these cities, a further two Brazilian women who were integrated into the social networks of the other interviewees (but who did not work in the sex industry) and with five Spanish clients. Most of my interviews were tape recorded with the consent of the interviewees.

4 My fieldwork also involved informal interviews with agents who worked for entities which offered aid to migrants and/or sex workers, Brazilian consulate workers in Barcelona and Madrid and officials of the Comisaría de Extranjería. I also conducted informal interviews with four owners of prostitution-orientated 
During my research in Madrid and Granada, I contacted several organizations associated with the anti-trafficking struggle and visited shelters for trafficked women. During these visits, I met no Brazilian women, though I heard some second-hand reports regarding them. None of my interviewees, however, understood themselves to be trafficked and the typical trafficking narratives talked about in the NGOs and shelters I visited did not correspond to my interviewees' own experiences as sex workers and immigrants.

In the first section of this paper I describe the debate on trafficking of people in Brazil and Spain, and comment upon certain aspects of the sex industry in the latter country, creating in this fashion a context for the reader's comprehension of my Brazilian interviewees' views and opinions. I then depict the interviewees' migration trajectories, the routes they followed to enter the Spanish sex markets, the way they traveled, and the principal notions and concepts under which they operate. In conclusion, I contend that these people conceptualize the phenomenon in a way that calls into question current understandings of trafficking as codified under national and international law.

\section{The notion of trafficking victims in Brazil}

The Palermo Protocol 5 is the world's recent most relevant attempt to develop a legal definition of the trafficking of human beings. The Brazilian government ratified the Protocol in 2004, in a context of intense social mobilization regarding the issue. The Brazilian process, however, demonstrated certain particularities in comparison with other nations' experiences with ratification. First of all, the participation by civil social movements was led by children's rights groups. Secondly, the process took place under fairly intense pressure from multilateral international agencies. Finally, the Protocol's adoption led to the co-existence of two different and conflicting definitions of 'trafficking' in Brazil: one based on the Protocol, the other on existing Brazilian law on prostitution. I will return later to this issue.

establishments, and in-depth interviews with 28 agents who worked for entities which offered aid to migrants and/or sex workers, as well as the legal representative for the Associación Nacional de Clubs de Alterne (ANELA) in Barcelona. My research also included analysis of secondary sources and material as well as migration statistics, academic research and reports regarding prostitution, media material (particularly articles in El País newspaper) and a Spanish internet site frequented by prostitutes' clients. 5 Protocol to Prevent, Suppress and Punish Trafficking in Persons, Especially Women and Children, Supplementing the United Nations Convention Against Transnational Organized Crime, 2000. 
Analyses of how the Palermo Protocol was prepared draw attention to the divisions between Anglo-American feminists over the issues of pornography and prostitution, and how these lobbies impacted upon the final version of the Protocol (Doezema 1998; 2001). While the debates regarding the "sex wars" raged on in the English-speaking world (Friedman and Thorne 1984; Chapkis 1997), the feminist movement in Brazil was engaged with other topics, which, by and large, did not focus on prostitution. In the 1970s and the first half of the 1980s, Brazilian feminism first concentrated on the struggle against the country's dictatorship, on combating domestic violence and, later, on health and reproductive rights (Moraes 1996; Corrêa 1984). However, according to women activists during those decades, prostitution was given some attention which generated new perceptions about sexuality and greater ambivalence in attitudes to the commercialization of sex (Piscitelli, 2011).

Gabriela Leite, one of the main Brazilian sex workers' rights activists, agrees with this analysis. In her view, things began to change in the $1990 \mathrm{~s}$ when some feminists considered that the prostitutes' movement should be recognized as an expression of female autonomy. Others, however, regarded prostitution as mere exploitation of women and refused to listen to the sex workers' voices ${ }^{6}$. Even so, the engagement of Brazilian feminism with concerns about sex work and sex trafficking grew gradually. ${ }^{7}$ Interestingly, though, towards the end of the 1990s, when civil society began to take up the struggle against the trafficking of people, the main stimulus came not from the feminists but from children's rights groups.

This struggle was intensified due to the political pressures and financial support from multilateral supranational agencies, in particular the UNODC. Under a technical cooperation agreement with the Brazilian government, the UNODC injected large sums of money to subsidize a series of activities undertaken by the government and civil society groups, which culminated in the formulation of Brazil's National Policy for Confronting Trafficking of People in 2007 (Ministério da Justiça 2007). The elaboration of this policy

6 Interviews with Maria Moraes, Bila Sorj, Sônia Corrêa and Gabriela Leite, conducted in São Paulo and in Rio de Janeiro, for the research: Tensões no feminismo contemporâneo, funded by CNPq and coordinated by Adriana Piscitelli, see: Piscitelli, 2011.

7 At the beginning of the 1980s, the Black feminist Lélia Gonzalez (1982) traced relationships between Brazilian mulattas, prostitution and tourism. But these relationships were conceptualized as sexual tourism and later conflated with sex trafficking by NGOs in cities of the northeast perceived as targets of sexual tourism. (Coletivo mulher vida, 1996; Chame, 1998). 
included widespread consultation with civil society movements and organizations but it did not incorporate any substantial interaction with Brazil's prostitutes' organizations, which had existed since the late 1980 s and saw anti-trafficking discourse as yet another means to combat prostitution, this time supported by widespread public opinion.

At the same time, the articulation between human rights organizations, government, multilateral supranational agencies, and transnational feminist networks ended up affecting some Brazilian feminist perceptions about prostitution; abolitionist perspectives started to be clearly delineated. Reacting against the effects of globalization on women, the Brazilian section of the Global March of Women fought against the commodification of females' bodies (Nobre e Faria, 2003). Prostitution and sex trafficking were both seen as extreme instances of such commodification.

From the second half of the 20oos, the trafficking of people became one of the main themes of diverse coalitions of women's groups, including the Articulation of Brazilian Women ${ }^{8}$, and through their engagement with the trafficking issue, some groups began to incorporate an anti-prostitution discourse as well9. In this way, echoes of the English-speaking world's 'sex wars' finally had an impact on Brazilian feminist discourse via the trafficking debate - 20 years after their formulation in the northern hemisphere. Although the Brazilian feminist movement is heterogeneous (Corrêa e Olivar, 2010) and includes perspectives that support sex workers' rights (Moschkovich, 2012), the groups antagonistic to prostitution are the closest to government (Secretaria Especial de Políticas Públicas para as Mulheres, 2008). This proximity lends much visibility to the perspectives that reject considering prostitution as work. Thus, the discourses proffered in international debates which situate sex workers as victims and which rarely take into consideration these women's voices (Kempadoo et al, 2005; Agustin 2007) became dominant in Brazil.

Brazil's prostitution laws can be qualified as following an abolitionist

8 See: Feministas de todo o Brasil presentes no I Encontro Nacional da AMB, 2006, in: http://www. institutobuzios.org.br/documentos/AMB_RELATORIO\%20I\%20ENCONTRO\%20NACIONAL.pdf

9 The Panel on Prostitution that took place in the Brazilian March, in Vinhedo, in 2010, gives an example of these positions. Considering prostitution as violence against women and as an expression of patriarchal oppression, the participants rejected calls for its legalization, a measure that in their opinion would not prevent sex trafficking. The panel concluded with a motion "against prostitution" to be disseminated throughout the country (Piscitelli, 2011). 
model in intent and scope. Although prostitution is not considered a crime, all activities surrounding prostitution are criminalized ${ }^{10}$. While Brazil has ratified the Palermo Protocol, the crime of trafficking in persons in Brazil continues to follow the Brazilian relevant articles of the Penal Code that was promulgated in $1940^{11}$ and altered in 2005 and $2009^{12}$. The Palermo Protocol considers a victim of trafficking to be someone who has been a target for fraud, coercion, abuse or the exploitation of some sort of vulnerability during the migration process leading to prostitution, other forms of sexual exploitation, forced labor or situations analogous to slavery'3. The Palermo Protocol includes several ambiguous definitions in its listing of situations understood to be human trafficking, particularly the expression "sexual exploitation." However, the Protocol does not automatically define migration in function of labor within the sex industry as trafficking, since such migration does not necessarily result in forced labor as such (Doezema 2001).

By contrast, the Brazilian Penal Code links trafficking exclusively to prostitution and, moreover, defines the crime as aiding or abetting the movement of women who will work as prostitutes, regardless of whether they consented, were exploited or suffered human rights abuses. Originally, this law was applied only to women involved in international travel as potential trafficking victims. However, recent modifications in the law have widened its scope to include people of all genders, and domestic as well as international travel. Differently from the Palermo Protocol then, Brazilian laws on human trafficking do not base their definition of the crime on the use of fraud, violence, threats or forced labor - these sorts of situations simply increase the crime's gravity, leading to more severe punishments. Since migrants usually receive some type of assistance, the Brazilian penal code qualifies almost any

10 According to the Brazilian Penal Code (chapter 5, articles 227 to 231), prostitution which involves people above the age of 18 is not considered a crime, but the exploitation of others - or pimping - is.

11 Chapter V, Article 231, 1, 2 and 3.

12 Law no 11.106, March 28, 2005, art 231a and Law 12.015-2009

13 The Palermo Protocol defines trafficking of people as: ...the recruitment, transportation, transfer, harboring or receipt of persons by the threat or use of abduction, by force or other ways of coercion, kidnapping, fraud, deception, or the abuse of power, or the receiving of payments or benefits to achieve the consent of a person having control over another person for the purposes of exploitation. Exploitation shall include, at a minimum, the exploitation of the prostitution of others or other forms of sexual exploitation, forced labour or services, slavery or practices similar to slavery, servitude or the removal of organs (United Nations Office on Drugs and Crime, 2000). 
migration for sex work as 'trafficking', and punishes as criminals anyone who aids these women during their movements.

The various interpretations of the migration of sex workers, which are made possible by the ambiguities present in the Palermo Protocol and reinforced in Brazil by the existence of distinct meanings enshrined in the penal code, have predictably resulted in significant divergences between how these migrations are seen and acted upon in any given situation. One of the most important effects of this juxtaposition is that police actions and judicial interpretations which have supposedly been undertaken to repress human trafficking in Brazil have, in fact, largely focused upon repressing prostitution, even in those cases where sex work involves consenting adults and no human rights violations at all (Castilho 2008; Oliveira 2008).

Since the implementation of the First National Plan against Trafficking in Persons in 2008 (Secretaria Nacional de Justiça, 2010) the Brazilian debate has diversified the definitions to include predominantly male "slave labor" in plantations and the capture of people for organ removal (Senado Federal, 2011). With the entry of diverse human rights groups into this arena, the strength of children's rights groups has become more diluted. (Sprandel e Mansur, 2010). Finally, the articulation between the government and the supranational multilateral agencies, particularly UNODC, has become less noticeable. Through innumerable courses and campaigns, the discussions about human trafficking have acquired capillarity, being adopted by diverse sectors of Brazilian society, at home and abroad. The Brazilian communities in Europe have been the target of itinerant courses directed towards potential volunteers in the fight against trafficking of Brazilian citizens ${ }^{14}$. One outcome of this effort has been to encourage people to collaborate in 'rescuing' Brazilian women and transvestites, not from trafficking but from prostitution, and to notify the police about venues where Brazilians performed sex work.

These practical effects of the 'anti-trafficking struggle' have tended to be ignored in public debates in Brazil regarding the phenomenon, which continue to concentrate on the 'trafficking as slavery' discourse. The materials distributed by anti-trafficking campaigns (especially in airports) offer an example of how the problem is still being perceived: posters and handouts

14 For instance, the Curso de capacitação para voluntários em questões de tráfico de pessoas, exploração do trabalho e violência de gênero, organized in Barcelona by the Brazilian Ministry of Foreign Affairs with the collaboration of the Brazilian Consulate in Barcelona, in November, 2010, that I attended. 
circulated by the campaigns generally show images of enchained, crying, imprisoned women. Another commonly held belief which increases social panic surrounding the trafficking theme (Grupo Davida 2005) is the idea that trafficking is somehow orchestrated by international 'mafias'. The overall effect of these campaigns and their propaganda is to cast a suspicious eye upon the social networks that have traditionally aided migrants in Brazil - especially when the migrants involved are poor, female, or transvestites. Within this new discourse of social panic, even migrants' relatives are considered suspect, liable to be accused of being in league with internationally organized criminal groups.

The different interpretations and the divergences of the definitions of trafficking and their effects are only now being publicly discussed in Brazil. Proposals to harmonize the two definitions are being mooted. However, they mainly consider the inclusion of 'slave work' and the removal of organs in the definition of trafficking in the Brazilian Penal Code. There are not yet significant attempts to change the definitions of sex trafficking, decriminalizing consensual, non-human rights violating displacements connected to voluntary prostitution (Blanchette 2008; Castilho 2008).

Within Brazil, the alliances between the government, NGOs, and social movements surrounding the anti-trafficking struggle quickly multiplied. Listening to the majority of anti-trafficking activists discussing the problem in the final years of the 200os, it was as if no legal contradictions and ambiguities existed. Within this context, a widespread and diffuse movement supported by supranational and transnational agencies and movements geared towards repressing prostitution began to take hold in the country's major metropolises. This movement generally used the rhetoric of 'rescuing enslaved victims' from the claws of 'international organized crime networks' as justification for the institution of anti-vice campaigns. This contextual background must be kept in mind as we turn towards our analysis of Brazilian sex workers' understandings of prostitution and migration in Spain.

\section{The sex industry and trafficking victims in spain}

During the 1990s, the internationalization of labor migration began to have a significant impact upon many sectors of the Spanish economy, such as domestic labor, work in the agricultural and fishing industries, and sex work. 
More and more, foreign laborers from several different parts of the world became a significant presence in these industries.

The diversified Spanish sexual industry that flourished until the 2008 economic crisis included sex phone lines, peep shows, strip clubs, erotic show halls, internet sites and the offer of sexual services in bars, along highways and streets, in rented apartments (pisos) and in clubs (Pons, Rodríguez and Vega 2002). Pisos were different from other venues in their organization, size and 'level' (as expressed in the prices charged and in the social categorizations of the workers active in them). Some employed female workers exclusively while others employed "trans" ${ }^{15}$; some had a mono-national workforce while others were diverse both nationally and ethnically.

Clubs concentrate a significant portion of the sexual services on sale in Spain. These venues are quite diverse, encompassing relatively small 'traditional' establishments (whose profits come from the sale of drinks and/or from a percentage of the sexual services negotiated on the premises) at one extreme, and the big hotéis-plaza at the other. These are organized according to the strictures of modern 'management philosophy' and during the boom of the sex industry some employed up to 150 women working and living there for up to 21 days at a time. In the hotéis-plaza, owners' profits came from the women paying to use the space and paying for food (Pons 2003).

Clubs and pisos are apparently going through a period of expansion, following the intensification of Spanish government programs aimed towards reducing the more public and visible offer of sexual services. Street prostitution is becoming absorbed by those closed spaces. ${ }^{16}$ In the first half of 2000 , under pressure from the European Union to reduce irregular migration and international human trafficking, Spanish laws regarding prostitution and migration were simultaneously modified17. The synergy between the two

15 A term used in Spain to designate transgendered individuals, including persons known as transvestites in Brazil.

16 Clubs are raided by the Police with a certain frequency. Apartments, however, only tend to get raided when the neighbors report them.

17 In the 1995 Penal Code, non-coercive prostitution involving consenting adults was not considered to be a crime. Pimping was penalized, but was only understood to be such when the pimp extracted money through abuse of power, coercion, or fraud (Mestre 2004). Because of the legal reforms discussed above, obtaining any money whatsoever from prostitutes, even when these were adults working voluntarily, became considered pimping. Furthermore, according to the new Ley de Extranjería (article 318 bis), it became a crime to aid illegal immigration, a crime considered to be aggravated if it involved migration for sexual exploitation (Cantarero 2007). 
new legal codes meant that the massive presence of foreign immigrants in the sex industry (who were often in Spain irregularly) was read almost automatically as proof of illegal activities, the result of human trafficking.

In 2006, at the high tide of Spain's social panic regarding prostitution, a congressional and senatorial committee opened up discussion on whether prostitution could be defined as work. The resulting fierce debate divided feminists, political parties and labor organizations, and concluded in 2007 with a request that prostitution should not be recognized as work as it is "a form of sexual exploitation, of violence towards women who are, in their majority, foreign and connected to human trafficking" ${ }^{\text {"18 }}$. It was then proposed that Spain create a national plan to control the open and public offering of sexual services. At the same time, the municipal governments of several cities gradually intensified the repression of street prostitution through the use of ordenanzas which restricted certain behaviors in public places, a form of repression of prostitution similar to that used in other cities of the northern hemisphere in neighborhoods slated for gentrification (Bernstein, 2007). In 2012 these measures were further intensified with new rules prohibiting street and highway prostitution. These led to public protests and the organization of new sex workers' collectives such as "Prostitutas indignadas"19.

The effect of this debate was to intensify the moral tone of Spain's antiprostitution campaigns, increasing the vulnerability of those people offering sexual services in the streets and along the highways. These sex workers became ever more subject to intimidation from the country's immigration police. These measures that have been considered as part of the fight against sex trafficking have resulted in the deportation of women who are irregularly in the country. Simultaneously, some municipal governments created plans to direct prostitutes towards other occupational sectors. Paradoxically, taking into account that most of the sex workers were considered to be foreign women with an irregular migration status, these plans were exclusively directed towards "regular" migrants (SURT 2007).

18 "La Comisión Congreso-Senado pide que no se regule la prostitución como trabajo." El País, 21/02/2007.

19 See: "Las prostitutas se manifiestan contra la ordenanza de civismo", La Razón, 27/04/2012, in: http:// www.larazon.es/noticia/4741-las-prostitutas-se-manifiestan-contra-la-ordenanza-de-civismo; "Medio millar personas protestan por acoso policial a prostitutas en Barcelona" , Notícias Terra Es, 26/04/2012, in: http:// noticias.terra.es/2012/mundo/o426/actualidad/medio-millar-personas-protestan-por-acoso-policial-a-prostitutasen-barcelona.aspx 
While foreign sex workers were systematically deported, during the first decade of this century, NGOs stated that in Spain there was no governmental protection for victims of trafficking who wanted to denounce their traffickers. ${ }^{20}$ Immigration police agents explained that by law ${ }^{21}$ they could only protect the victims when they presented complaints that offered new and consistent evidence about criminal organization $s^{22}$. These dynamics did not change with the implementation of the Spanish Plan Against Trafficking in Persons that is exclusively directed towards sex trafficking and fuses prostitution with sex trafficking (Gobierno de España, 2007). Recent reports about women kept in custody in the highly feared CIES, the centers where irregular immigrants are locked up before being deported, state that several foreign victims of trafficking in persons are held in anti-humanitarian conditions without any recognition of their status as victims (Women's Worldwide link, 2012).

During the 200os, many reports pointed to a significant presence of Latin American women (including Brazilians) in some regions and niches of the Spanish sex industry. Some of these women worked in the street, but were concentrated in closed spaces: pisos and clubs of varying size. The opinion of the representative of the Asociación Nacional de Clubs de Alterne in Barcelona confirmed this impression. According to him, some 14,000 women were at work offering sexual services in the Association's establishments during the second half of the first decade of the $21^{\text {st }}$ century. Of these workers, some $40 \%$ were from Eastern Europe (Russians, Romanians, Czechs and citizens of the successor nations of Yugoslavia). Latin American women - mainly Brazilians and Colombians, though also Uruguayans, Venezuelans, Dominicans and very occasionally Argentineans - made up another 40\%. Black African women, considered to be inferior, had a smaller presence.

\section{Routes}

The Brazilian women I interviewed were very diverse in terms of their insertion in the sex industry, the amount of time spent in Spain, their legal

\footnotetext{
20 Interview conducted with members of the NGO AMBIT DONA, in Barcelona, September, 2005.

21 Lei orgánica 4, artigo 59, 2000.

22 Personal communication of a Police Agent during the Seminário de Formação em Combate ao Tráfico Internacional de Seres Humanos that took place at the Auditório do Cedim, in June 27, 2005, in Rio de Janeiro.
} 
situation, age, state of origin, and skin color. Research has shown, however, that in spite of this diversity, certain patterns were recurrent in the opinions held with regard to sex work and human trafficking.

These women worked mainly in clubs and pisos, but some also worked the street. The amount of time they had spent in Spain varied between one and ten years. All had entered the country as tourists. Spain does not require tourist visas for Brazilian citizens, but does restrict their stay to three months. Only seven women had obtained legal residency, most of them through marriage, and only one had subsequently stopped working in the sex industry. The rest of the women were in Spain irregularly and were fighting extradition and "expulsion notices" ${ }^{23}$ and had begun the legal struggle to remain legally in the country and to avoid deportation.

Brazilian women working in the European sex industry tend to be imagined as very young and very poor mothers, black or dark-skinned, with low levels of formal education, from the country's poorest states and without any prior history of work in the sex industry. It is also imagined that they have largely been exposed to fraud and/or violence on the part of 'trafficking mafias' who cynically manipulate these women's socio-economic vulnerabilities to entrap them in a situation analogous to slavery. The profile of my informants puts these stereotypes into question.

Some of the younger (around 20 years old) women I interviewed moved into the European sex market upon completing adolescence. Others, however, were in their 30 s and some were even in their 4os. This latter group of women struggled with the fact that their age was considered "advanced" in Brazil where they had to struggle increasingly to make money in the sex trade. For these 40 year olds, migration to Europe became a way of extending their careers as sex workers, given the fact that prejudices against more mature women are felt to be greater in Brazil. As one of my informants, whom I will call Olivia - in her late forties, from Minas Gerais, considered herself white, had high school education and sex work experience in Rio de Janeiro and São Paulo - put it:

Here [in Spain] there are women in their 7os who are still working...In Brazil, men have that mentality that only young women, 18 to 20 , are worth anything. In Europe, it's different...Here if you're 70, you can still make money...Even

23 A document issued by the immigration police which demands that the migrant leave the country. 
find a husband...I have clients who range from 18 and 20 years old on up to 90. (Barcelona, December 2004)

The level of formal schooling these women have received is, indeed, relatively low, with only one having attended university, but most of them have more years in school on average than is the norm in Brazil. Some were born in the poor states of the Brazilian Central West and Northeast, but others came from regions considered to be relatively wealthy in Brazil: the South and Southeast. Only four had left children behind in Brazil. In terms of the racial classifications currently operative in their homeland, most considered themselves to be white or morenas claras (light brown) and only two thought of themselves as brown or mulatta. Most of the women described themselves as lower middle class at the time of their migration from Brazil and only two as members of the lower classes. Economic conditions were considered an important factor in their entering the Spanish sex market, but this in no way signified that their lives in Brazil could necessarily be considered to have been miserable. Most of my interviewees spoke of a feeling that they lacked an economic "future" in their country of origin. According to Olivia:

I don't need to be away from my family in order to eat. In Brazil, you can plant manioc, raise chickens. You'll eat, all right. It wasn't hunger that made me come here: it was me trying to do something with my life....I've always worried about tomorrow, about what things will be like when I'm 60 . (Barcelona, December 2004).

Most of my interviewees worked in the sex industry in Brazil prior to migration, having previously worked in other activities in both the formal and informal sectors of the economy ${ }^{24}$, as baby-sitters, maids, factory workers, waitresses, schoolteachers, saleswomen, secretaries, and even minor businesswomen. They say that these forms of labor are more poorly paid than sex work, especially taking into account the amount of labor required for money earned. This, they claimed, was the principal motive leading them to work in the sex industry.

While still in Brazil, some women did programas ${ }^{25}$ only intermittently. Two of them had Brazilian and foreign clients for brief periods of time in Rio

24 It is important to remember that my research is qualitative and I thus do not intend to make generalizations. Other studies have uncovered the presence of Brazilians in the European sex industry who had not done sex work prior to immigration (Ministério da Justiça 2006).

25 An emic term which is the Portuguese equivalent to the English trick. 
de Janeiro or in the loosely organized sexual tourism of the Brazilian northeast. Others, more 'professional', survived exclusively on programas for several years before finally migrating to Europe.

Most of the interviewees migrated with the express purpose of working in the European sex industry. One, however, came to Europe to work as a nurse and only later decided to go into sex work upon learning that this paid far more, at least before the economic crises. Two women interviewed in the last phase of the research had a different profile. They were migrants who had not done sex work in Brazil, nor had they intended to do so in Spain until they lost their jobs due to the recent Spanish economic crisis. They entered the sex industry in the hope of being able to continue their migratory projects in Spain.

Most of my interviewees portrayed sex work as tempting due to the difficulties migrants - and especially irregular migrants - confront in finding well-paid work that is not subject to extremely exploitative conditions. They emphasized the relative advantages prostitution offered over other kinds of available work in terms of flexibility of labor conditions and benefits gained for effort expended. In Olivia's words:

If I were to work in anything else...what would I have left over for me? Cleaning floors...You make so little and that's the problem. If I were to make a lot, I'd sweep the streets....But to work for 800,900 euros [a month]? No way. I like working as a prostitute. Some people say it's easy money, but it isn't. However, you do have more opportunities to make more money...Our advantage is that we're free. You're free to do what you want! (Barcelona, December 2004).

The women who were newcomers to the sex industry, having entered it after losing their other jobs, also highlighted the economic advantages of prostitution. Bela, a woman in her mid-thirties, with high school education, who considers herself morena clara and who moved from São Paulo to Vigo, where she worked in a restaurant until she was fired in 2009, and afterwards started reluctantly to perform sex work in Barcelona, had this to say:

I was paying 350 euros for a room in Barcelona, it was cheap but I had no money. Upon arriving I sent more than 500 curricula. And I did not find a job. During the first weekend in which I worked [as a prostitute] I earned 500 euros, in just one afternoon, from 13 h to $18 \mathrm{~h}$. Then you stop and think, to earn this I would have to work from Monday to Friday, 4 hours, cleaning, cooking, ironing...Then you do not want to look for employment any more. 
I was just hoping that nobody who had received a curriculum would call me. (Barcelona, February, 2010)

Only one of my interviewees returned to Brazil when her tourist visa expired and declared that she wouldn't be coming back to Spain. However, once back in her home town, a comparison of the local Brazilian sex market with that of Bilbao made her decide to return to Spain. Said Kelly, a 24 year-old woman from Natal, with high school education, who considers herself morena clara and did programas with foreigners in the sex tourism circuits in Natal until her $18^{\text {th }}$ birthday:

I started comparing what I made here and what I made there and it didn't make sense to stay [in Brazil]...This was in 2000. One programa with a grin$g^{26}$ back home would make me 10oR $\$$ USD50\$] and the same thing with a Brazilian was only 30 or $40 \mathrm{R} \$$...And in Brazil, you have to stay all night with the man, whereas here it's only 20 minutes...If you're with someone you don't like - a fat old man, for example - it's horrible to have to spend the night with them...When you're with many different men, things change at least. One's more handsome, another nicer, another cruder...What really weighs on you is knowing you'll have to spend the whole night with one man for 10oR $\$$ when here you could have made 3 or 4 thousand Reais in the same period if you really put your mind to it, understand? (Bilbao, December 2004).

\section{Journeys}

Studies of trafficking in persons focus on travel in order to offer clues for detecting networks operated by organized crime. My interviewees report three types of international voyages. The first type of travel is undertaken autonomously and voluntarily. It does not involve indebtedness, nor a large number of intermediaries. The women pay for their own trip and travel with the express purpose of finding work in the European sex industry. Olivia describes the process as follows:

I worked [as a prostitute] in São Paulo and I heard the women coming back from Spain and talking about how good it was over here. So I bought a ticket with my own money and I invited two other girls to travel with me. I brought along 800 USD. I had a contact address over here in Coruña [in

26 An emic term used to refer to foreigners. 
Galicia]. This place was a club, however, and an older woman like me doesn't make much money in clubs. So we came to Barcelona. I began to make money [working on the street] at Carrer Sant Ramon (Barcelona, November, 2004).

Debt is the principal characteristic of the second type of travel, where overseas airfares are financed by Spanish clubs and necessarily involve wider networks of people. In some cases, the women are contacted in Brazil. In others, the women invest time and effort in order to obtain the necessary contacts. The women who migrated from different Brazilian cities to work in clubs in Bilbao and Almeria, talk of these intermediaries and tell of debts that practically triple the normal price of an air ticket. Samara, a forty yearold woman from Rio de Janeiro, with incomplete high school studies, who worked for ten years in clubs in Bilbao stated:

I worked in Rio de Janeiro. An Argentinean contacted me and asked me to come to Bilbao. The problem is that he wanted to make too much money off me. Through him, I came directly to the club in Bilbao (Bilbao, December, 2004).

Kelly, from Natal, gave a detailed description of the way she organized her travel and the amount of debt incurred:

I used to go to a disco...There was a taxi driver I knew who'd take me there and he'd say “Girl, don't you want to go overseas to work?"...He said I could make a lot of money....He helped us get our passports...We came...through Paris. I didn't realize what a risk we were running if the police caught us...We came here by bus from Paris...As soon as we arrived in Bilbao, we called the person who was waiting for us... and they came to pick us up...Later [he] took us to the club...The cost of the journey was 3 thousand euros.....and we had to pay the club 40 euros a day. I got desperate when he told me about the 3 thousand euros....Our passports stayed with us and our return tickets home, too...I spent several days crying...the guy who picked us up at the bus station asked if I wanted to go home. This was without me having paid off the debt... I said no, because I didn't want to have any trouble with these people. I said I'd pay off the ticket and then go home if that was what I wanted. And I paid everything off in a month - less, even...What I made afterwards was mine alone (Bilbao, December, 2004).

One of my interviewees, who I'll call Verônica, a woman in her late twenties who considered herself white, with incomplete college education, and 
who performed 'high-level' sex work in São Paulo before traveling abroad, told of the efforts some women make to enter the European sex market:

It took me a while to find out how to get to Europe. More than a year...I had a friend who had a friend...And that's how we got the information, at a travel agency...First, I went to a club in Almeria, which wasn't a good place. But I had a friend who had contacts with another girl in Barcelona who had worked in a club and was a good friend of the owner. The woman who owned this club in Barcelona sent money for us to pay off our debt...[When I arrived in Barcelona], I still had to pay off 800 euros, but in the first week I got lucky: I made $1700 \mathrm{eu}-$ ros, paid off my debt and had money left over to send back to Brazil (Barcelona, September 2006).

The third type of travel, that which involves informal networks of friends, acquaintances and relatives who are already living in Spain, is the most common among my informants. These networks are analogous to those used by other types of Latin American migrants and, in the past, Brazilian internal migrants who came down from the north and northeast of the country to look for work in the southeast (Scott, 2011). The main difference is that the networks that are activated to gain work in the European sex industry are basically made up of women and, in particular, friends, neighbors and relatives. This type of trip may or may not involve incurring debts. When it does, the interest rates are similar to those charged by clubs and discussed above. When this interest is not "excessive," it is seen as "logical" and is understood to be an "obligation" to pay back the "help" received. Olivia made clear her disgust with the girls she "helped" to travel but who had failed to pay her back:

I brought five girls over here. You help with the costs of the ticket, you loan money. When they get here, they screw you over...They don't want to pay you back...Now, with the mafias, no. They take your passport, understand...? If I decide to bring someone over again one day, I'm going to charge first in Brazil and THEN bring them over... (Barcelona, December 2004)

When a plane ticket is a present that is part of kinship reciprocity circuits, this kind of trip doesn't require the migrant to pay back any debts. According to Verônica, who was "helping" her sister to leave Brazil: 
My sister was [studying] production technology in Brazil. Her classes ended in December and seeing as she couldn't find work, I paid for her ticket for her to come to Spain. Here, she was able to work part time in her field and part time in prostitution, which is where you make real money (Barcelona, February 2008).

According to the Brazilian Penal Code, all three of the modes of travel described above can be understood as the criminal international trafficking of people. As is the case with any migrant, all of my interviewees had some sort of support for their journey overseas and/or for joining the Spanish sex industry; this can be legally understood as 'facilitating trafficking.' Some women, in fact, were both 'victims of trafficking' and 'traffickers' at the same time, since they had helped other women migrate and/or find work in the sex industry. In defining trafficking strictly according to the Palermo Protocol, however, only those trips that were subsidized by Spanish club owners combined two elements that are necessary for defining the crime of human trafficking: the involvement of transnationally organized groups, and indebtedness. However, such behavior may only be legally defined as trafficking if it also includes 'exploitation'.

The Palermo Protocol more thoroughly explores the concept of exploitation when it discusses economic activities outside the sex industry. In these cases, exploitation is clearly associated with the idea of forced work, slavery, or servitude ${ }^{27}$. The concept becomes murky, however, when sexual exploitation is discussed. This term is not defined by the Protocol and, as we've discussed above, its meaning is hotly debated.

Abolitionists consider sexual exploitation to be any sort of prostitution, including the sale of sex by consenting adults who work for themselves. They see prostitution as an act in which sexuality itself is the object of violence, provoking deep wounds in the prostitute's psyche due to the abuse and dehumanization to which she is subjected (Barry, 1997). By contrast, those understandings of prostitution that support sex worker organizations make a clear distinction between prostitution and exploitation. In this line of thought, exploitation is linked to the characteristics of the global labor market (Kempadoo, 1998). This understanding of the prostitution/exploitation dyad maintains clear congruencies with my interviewees' testimonies.

27 This point becomes evident in the judicial decisions of the European Supreme Court for Human Rights, in which notions of "exploitation" are clearly outlined in cases involving human trafficking for domestic labor. This clarity disappears, however, when the topic becomes trafficking for sexual purposes (Munro 2008). 


\section{Exploitation}

Work conditions in the Spanish sex industry change in accordance with the occupational niche, type and 'level' of the establishment; the region of the country in which it is located; and the immigration status of the workers involved. Furthermore, the conditions are changing as a result of the economic crisis. My informants differed on which sort of work venues they preferred. Clubs were generally more appreciated by the younger women, because they offered work conditions that they considered to be adequate, and due to the possibility of making a lot of money and of working together with other girls of the same age. These aspects of club work were made explicit by Kelly, who worked in a club in Bilbao at the beginning of the 200os:

Some days you can turn 3 or 4 tricks and some days $5,6 \ldots$...He [the club's owner] charges a daily club use fee and the rest is yours.... made up to 400 a day, myself. But then, I wasn't the kind of girl who'd keep her nose to the grindstone. For me, club work was mostly fun, because I was with my friends and we'd always talk about the fact that we lost a lot of money because we'd sit around and talk to each other instead of working the clients...In the bar or the club, you're with the client and the client buys you a coke, which costs 18 euros, 9 of those euros are yours...If he buys a 6 euro bottle of water, half or that -3 euros - was yours. How much would I make...? I threw away a lot of money by taking breaks and holidays...We'd travel and stay in top-rate hotels, take taxis and I regret all that now, for not having taken better advantage of my situation. We lived in the club and ate at the restaurant just like normal people...If you didn't eat there, they gave you back your money. You could have boyfriends, even, but it was like “OK, but whatever you do, please be here at 6 PM...” (Bilbao, December, 2004)

The interviewees who work in the streets criticize the clubs for charging fees or for retaining part of the cost of each 'trick'. These women say that although they only charged about half of the cost of a club programa, they ended up making almost as much as club girls, simply because they paid no fees and suffered no deductions. Aside from this, the street workers stated that the street offered other advantages: they could set their own hours and maintain social contacts, which were not involved with sex work. According to Olivia, who worked for a few days in a club but now offers sexual services for sale on the streets: 
I've already worked at Club X....and it's not good, because you have to work nights, which I don't like. You have to take plazas ${ }^{28}$ for 21 days at a time and during that period, you don't see anyone else...You have to drink with the men. You have to always be nice, ready to chat...I prefer this kind of life. I work days, I can meet with friends and, if I want, I can quit work at any time and go window-shopping. You really don't make more money in the clubs. You make more, actually, but you also have to pay the club fee...There are many places on the street where you can make a lot of money...4 thousand euros a month, on average... (Barcelona, November 2004).

The retention of part of the money earned through programas in the apartments is seen in a different way. When I started the research, I was amazed at the $50 \%$ fee on programas in the apartments. My interviewees, however, thought that arrangement was relatively fair. From Bela's point of view:

Of course it is better to have your own apartment. But when you cannot, working at $50 \%$ is not so bad. You have to think that the owner pays the rent, water, electricity, pays for the web announcements and when you do not work you do not pay, but you still live in the apartment (Barcelona, March, 2010).

Among my interviewees, the concept of exploitation was purely economic and never sexual in nature. Some considered any portion of money retained by others from the cost of tricks to be exploitation. Others thought that exploitation existed only when there was clear financial abuse through excessive retentions and deductions. Verônica clearly defines this second concept of exploitation in terms of work relations. Her narrative describes the kind of work conditions which are possible for a sex worker in a country that refuses to decriminalize prostitution, especially when this situation is aggravated by irregular immigration status, which includes exposure to violent situations.

Verônica went to Spain to work in a club in Andalusia believing that she would be making 100 euros an hour. Only after her arrival did she learn that half of this would be taken by the house itself. Due to a "slow period," after a month of work she still hadn't paid off her debt of 2500 euros. Verônica didn't like the work conditions in the club, which she considered to be bad and insecure: "the clients were mainly Gypsies and Moroccans, which are the worst 
clients for us, because they put knives to the girls' throats." Later, Verônica worked in a club in Barcelona, where security was better and the clients were generally "calmer" Spanish and occasionally foreign tourists. She still felt exploited in this second club, however:

They exploited me. I paid 450 euros a months for the room I divided with three other girls; I couldn't use the phone to order food and the manager charged an absurd 20 euros for even a small pizza. At the club in Almeria, the exploitation was less and we could go out and buy our own food (Barcelona, February, 2008).

In Barcelona, Verônica paid off the rest of her debt in two weeks. After a time, belonging as she did to a widespread network of social relationships, she was able to rent an apartment with colleagues from work, a situation which she considered to be ideal because costs were shared evenly. She "earned well" for a time, but work became harder to find in Spain because "more girls began to show up and there was a lot of competition." Verônica's body style is in accordance with the preferences of Spanish men who have sex in mid-level prostitution niches. She is slender but well built, with delicate body movements, harmonious features, light-colored skin and dark silky hair. Her physical characteristics would have made it possible for her to work in "good" apartments in Barcelona, which were sophisticated, safe and expensive. But she couldn't do this because of her lack of "papers."

Verônica began to work in apartments in the smaller cities of Catalonia, which were less secure. In one of these, she went through the most dramatic situation she ever faced in her sex work career: "I was working...and a client tried to kill me...He's in jail now, accused of rape and battery.” Following this traumatic experience, Verônica decided to work in a safer environment: a massage parlor, which accepted undocumented immigrant workers. In one of my last meetings with her, she reported that she was only working days and felt safe because her clients were "normal people". She complained, however, that she wasn't making enough money.

\section{Sex trafficking}

Verônica associates the concept of violence with the experience she lived through, described above. But she also sees violence in human trafficking, which she understands to be a synonym of slavery: 
The slaves...now those people are victims. I met one. Her father sold her when she was 16 years old. This happens a lot with the Romanians and Bulgarians. Once, on the street, one of them began crying and begging us to help her get out of there. These girls want to escape, to go back [to their parents], even if they have to be deported to do so (Barcelona, February, 2008).

In Verônica's view of things, however, there's an immense distance between the experiences of victims of trafficking and her own experiences as a prostitute, a point that was reiterated by all my interviewees. The way these women think about their experiences, then, and the way they think about human trafficking is quite different from the abolitionist feminists, who see trafficking where there is prostitution. The interviewees contest notions present in the Brazilian legal code regarding the crime of trafficking, but repeat some of the ideas and themes that are present in anti-trafficking campaigns and the Palermo Protocol. However, the women modify these concepts, attributing specific feelings and meanings to generic terms such as coercion, organized criminal groups, fraud, abuse of vulnerabilities, exploitation and violence.

According to their view of things, trafficking is synonymous with deprivation of liberty and forced work. It is something that's linked to 'mafias', understood as organized criminal groups. These Brazilian women, however, believe that such 'mafias' control women from other parts of the world and especially from Africa and Eastern Europe. Olivia was quite explicit in distancing herself and her Brazilian colleagues from these groups:

Mafia is when a woman is enslaved, imprisoned. When she's sold. That happens here with the Romanians. But then the police go and arrest those women and not the men who are out there on the streets running the show! And those girls have to work whether they want to or not. They can't stop to eat and they have to eat what's given to them (Barcelona, November, 2004).

If a woman doesn't know that she needs to repay a loan for a plane ticket, with interest, this is seen as either innocence or "stupidity" on her part, not as the result of fraud. It is also not seen as being necessarily an indication of human trafficking: for that to occur, according to the women, a person needs to be imprisoned or enslaved. The fact that a woman is "watched" while she's in the process of paying off her debt is not understood to be a form of imprisonment. These definitions are quite clear in Verônica's testimony, when she claims that the club where she initially worked did not limit her movements 
or confiscate her passport, only "watched" her. In order to demonstrate that she was not obliged to stay at the club, she explained to me that one of the colleagues with whom she migrated ended up returning to Brazil without paying off her debt and was able to do so without any problems.

Indebtedness is considered a phase in the migratory process of those women who do not otherwise possess the necessary resources to migrate. It is also associated with two other concepts which are, in turn, linked to different forms of international movement: "deals" and "help". My interviewees believe that when they become indebted to the owners of clubs they are making "deals," as in any other form of commercial transaction. The fact that these club owners belong to international networks does not transform them into members of 'mafias'. Olivia defined the situation in this manner:

What is a mafia? Is it charging twice the cost of the plane ticket? That's not a mafia... you want to go to Europe, but don't have money for the ticket. The ticket costs 1000 euros, I buy it for you because I have money, but I want 3000 euros in return. You accepted the deal. It's a done deal. Period (Barcelona, November, 2004).

"Help," on the other hand, is linked to travel undertaken with the aid of informal networks made up of people who are close to the migrant. It involves temporary loans of money, which are repaid with interest similar to that charged by a club for a similar service. It may also involve an offer of a high-priced vacancy in an apartment and/or aid in inserting oneself in a given point on the street. It's worth pointing out here that these sorts of practices are commonplace among migrants in other economic sectors (Oso Casas 2005). Those of my interviewees who "helped" with the migration of other Brazilian women charged interest of around 100\% on the loans they made. They believed that they were acting in accordance with an economic logic that is present throughout today's international migration circuits, and also felt that they were basically doing a good deed: "helping" colleagues to take the first steps towards building a better life than the one they had in Brazil.

Exploitation - that rather imprecise notion much mentioned by the Palermo Protocol and exclusively defined as economic in nature by my informants - may or may not be associated with payments of the kind of debts described above. Having had widespread experience with many types of poorly paid work in Brazil and perceiving the relationship between work 
and the kinds of salaries paid to migrants in Spain, most of my interviewees consider exploitation to be a situation in which most of the money made by them is retained by someone else. Thus, exploitation of and through indebtedness is associated with Nigerian immigrants, who need to pay off 30,000 or 40,000 euros.

In analogous fashion, house fees or "the house's part" paid in clubs and in some apartments may or may not be perceived as a form of exploitation. Even in those cases where it is understood to be exploitative, however, this sort of exploitation is not in and of itself enough to qualify a situation as trafficking; in order to be a victim of trafficking, one must be enslaved or forced to accept the exploitation.

My interviewees also differentiate abuse from the concept of a "situation of vulnerability." In the international debate regarding trafficking of people, the concept of abuse of a situation of vulnerability is linked to migration from the poorer regions of the world. In the Brazilian discussion, the term is linked to those women who are poorer and with lower levels of formal education, those who migrate from regions that are distant from the country's metropolitan centers, black women and, occasionally, younger women. Among my interviewees, however, regardless of their age, class, or educational level, migration to work in the Spanish sex industry was undertaken in accordance with a strong belief that at the time Brazil offered few opportunities for a better life. In this sense, then, these women's perceptions of their social 'vulnerability' in their home country served as impetus for migration in search of new economic opportunities.

My interviewees had a clear idea of what constitutes violence but did not link this automatically to programas. For them, violence involved physical or moral damage, suffered by other woman at the hands of "mafias." Violence also occasionally appeared linked to clients and, to an even greater degree, to the Spanish State, represented by the immigration police. It was evoked, with much anger and fear, when the women referred to the Spanish government's anti-trafficking activities. In the words of Alice, an attractive woman from Rio de Janeiro, with incomplete high school education, in her late thirties, with long hair and green eyes, the only interviewee who considered herself a mulatta:

I do not know any Latin American woman who was forced [to come here or to 
work in the sex industry]. They're looking in the wrong places because they are looking for trafficking victims among those of us who came here because we wanted to. They arrest people because some of the girls in the clubs are working illegally. They arrest people for lacking immigration papers and for this reason the women are detained and deported. Some of these women have just paid off their debt and right when it becomes possible for them to actually start making money, they get deported...What they do is deport women who don't have the proper papers but who know that they came here to do and want to do it! (Barcelona, November, 2004)

These sex workers considered anti-trafficking activities to be a means by which the Spanish government facilitated the deportation of irregular Brazilian immigrants. In the experience of my interviewees, trafficking was not the greatest threat they faced: it was the Spanish government's anti-prostitution and anti-immigrant activities that worried and frightened them the most.

\section{Victims?}

In a recent discussion, Stenvoll and O'Connell Davidson (2010) pointed to the ambiguities regarding the use of the 'victim' category in the contemporary debate on human rights. In their view, it is a complex category whose meanings range from the harmed party in a crime to someone injured or damaged by broader socio-economic or political structures and events. According to these authors, victimhood is ascribed to, or claimed by, individuals or groups in various social and legal contexts, and has become an important, as well as politically charged, status. Being represented or representing oneself as a victim is often a first step towards having one's suffering, and with it one's claims to rights, socially and legally recognized. Yet victimhood is also a risky identity to claim, or to have claimed on your behalf, because to be recognized and cared about as a victim can mean being stripped of agency and viewed as an object. It also might encourage a tendency to imagine the global population as divisible into a series of distinct and hierarchically ordered subcategories in terms of their needs and entitlement to rights and protection, and in terms of their capacity for agency and political participation.

According to the Brazilian Penal Code my interviewees could be considered victims of crime. Yet, they would have had difficulties in being recognized as such by the Spanish Immigration Police. However, the notion of 
victimhood was far from their universe since they perceived their migratory trajectories and sex work as paths for the improvement of their lives.

Like Brazilian immigrants in other sectors of the labor market around the world (Assis 2004), sex workers in Spain maintained tight connections with their homeland. Though they had many different plans for the future, these tended to revolve around the idea of returning to Brazil and generally involved investments in projects for the social protection of self and family through the acquisition of goods in Brazil and through the gathering of savings, which supposedly would guarantee a tranquil old age.

The women who were legal immigrants traveled regularly to Brazil, using the opportunity to reinforce personal relationships, especially with relatives. They also used these trips to seek out profitable economic investment opportunities, which were associated with the idea of their permanent return over the long- or medium-term. Real estate was seen as a valuable acquisition. Three interviewees bought houses or apartments in Brazil and one of them bought land and cattle. Thus, sex work in Spain was directly related to lucrative investments in Brazil. According to Olivia:

All the money I make here I invest in Brazil...Because two, three, four years down the road, that's where I want to be, with my family. I have land there, some cows...in Rondônia....my son takes care of things for me. I send money every month so that two years from now I won't have to work at all. I send about 1,50o euros [a month] to Brazil. For this reason, I've always appreciated what this here [in Spain] is. I'm patient with the old [clients] because I know that the 20 euros they give me for 20 minutes [of sex] pays four days of a cowboy's salary back home. You need to have a wide view of things. I want my cows over there to be shitting money for me... (Barcelona, September, 2006).

Most of these women recognized and honored kinship obligations to their children, in those cases where these were left behind in Brazil, but also to mothers, brothers and cousins. Family obligations were manifest in purchases of goods and payment for house refurbishing and reform, as well as in monthly remittances of money and further remittances on special occasions. Moneys were sent back via wire transfer and varying between 100 and 1,500 euros per month before the economic crisis. According to Keyla, Ana and Verônica: 
My mother lived in a mud hut in Natal... I rebuilt her house, with five bedrooms and a patio with a tiled floor. I bought a refrigerator, a TV,, a wardrobe...Everything in that house from the spoons to the plates, I bought. I wanted to give my brothers the things they'd never had. I bought a bicycle for each of them. They're like my sons. Every month I send 100 euros - more if there's an urgent need (Bilbao, December 2004).

My whole family's there [in Rio]. My mom..., my brothers, my cousins...I don't have children, but I send money every week. I get the feeling that the whole family lives off this money (Barcelona, November, 2004).

I send money every month. I pay all the expenses in the house where my mother, father and sister live in São Paulo. Aside from this, I pay for a house I bought. I send at least 800 euros a month. 600 for rent and expenses and the like and 200 for my house, which is being paid for in small installments (Barcelona, September, 2006).

For these women, remittances of cash and presents were part of a continuous circulation of material and symbolic goods. These exchanges offer significant resources to members of the kinship network who are in other countries. As is the case with other women migrants in other sectors (ViruellFuentes 2006), phone calls, were extremely important sources of moral support, especially for the more isolated women. At the same time, these phone calls were a way to interfere in family life on the other side of the ocean. Through these contacts, my interviewees maintained a daily presence in the lives of their home social circuits and regularly interfered in the lives of the people they were helping. Transnational circulation of goods also had political effects, amplifying these women's influence.

My interviewees also reported "gains" which went beyond the strictly material or familial. These included the widening of their cultural horizons due to these social interactions and this, in turn, prompted a re-evaluation of Brazil. But aside from this, such contacts also ended up creating new autonomies and new gender-based projects. In the words of Olivia:

Working in prostitution here you end up learning a lot about different cultures and histories. I find this to be enchanting. Here in Spain, you also live with the French, English, Germans and Greeks. So when I leave here and go 
back to Brazil and talk to people, I see how big I've become in cultural terms, understand?... it was as if the world opened up to me, understand? (Barcelona, November, 2004)

Sirlene, a woman from Bahia in her late thirties, who considered herself morena clara, with elementary studies, offered sexual services in the street in Barcelona, and interviewed a few weeks before being deported, explained:

Now I'm not gonna want to limit myself to just one man. Now I want to have who I want...We cook, clean and care for them and they're always on the lookout for someone else. No, now I want him to cook, clean and care for me. Now my mind's changed and I tell him, "Now that woman you knew is someone else. Now I'm the one with the cards in my hand" (Barcelona, November, 2004).

In the midst of these gains, violence, and commercial exploitation, these women - even those who saw themselves as white - also saw themselves as subject to a process of racialization which was linked more to their nationality than to their color per se. This process was expressed in the Spanish view that Brazilian women have certain "tropical" qualities such as a sensual, tender and "hot" temperament. These qualities sexualize Latin American women in Spanish eyes. These ambiguous stereotypes can be used in racist fashion to situate Brazilians as inferior. My interviewees, however, tended to use the stereotypes in a strategic manner by attempting to transform them into factors which created extra economic value for their activities on the sex market. According to them, the stigma associated with prostitution (Garaizával 2005) - more intense in Spain than in Brazil - affected them more seriously than racism.

As is the case with other forms of migration from the world's poor regions, these Brazilian women operate in a structural framework characterized by unequal intersections of gender, sex, and nationality/ethnicity. Their strategy of leaving Brazil did not free them from being seen as inferior in their new lives overseas. However, migration offered ways to escape from the webs of inequalities in Brazil. In this sense, those readings of migrant experience which are not simply orientated by 'western' feminist values, but which pay attention to third world women's subjective experiences (Ong 1999), have greatly aided me in reflecting upon my interviewees' testimonies. This requires me to situate their experiences within the interconnected web of material and symbolic processes that make up translocal systems of gender. 
In Brazil, the economic activities of these women were already precarious; they were stigmatized and poorly paid. In general, my interviewees considered their work in the Spanish sex industry to be superior to prostitution and to other forms of work in Brazil in terms of benefits earned for labor expended. They perceived their lifestyle in Europe to be better than that which they had in Brazil and this was a central point in the permanent comparison they established between the two nations. The social mobility, which many of these women obtained in their trajectories of transnational migration, had positive effects upon their possibilities for social agency. In the contrast between their experience in Brazil and Spain, which these women persistently noted, they clearly saw their migration to Spain for sex work as a source of material and symbolic gains. Above all, they highlighted the fact that they were much better off than those whom they left behind in Brazil.

\section{Concluding remarks}

My interviewees described migratory flows that involved several different types of travel but emphasized trips that are undertaken with the support of informal interpersonal networks. Such travel always involved other people's "help" and sometimes indebtedness, but cannot be considered to be the result of the activities of organized international criminal groups. Ethnographic work reveals that, to the contrary, we must problematize the generalizing narratives regarding sex work migration that currently limit both the sexual rights and the free movement of sexual workers across international borders.

Economic rationality and creativity are intertwined in the practices of these Brazilian sex workers. They used the cultural configurations that assigned them an inferior position in Europe, but which also made them attractive as workers in the sex market. They also employed strategies of social mobility which often resulted in concrete improvements in their life conditions and in the life conditions of their loved ones in Brazil.

According to Judith Butler (1990), subversion is linked to movements that interrupt the hegemonic cultural order. The inequalities that mark my interviewees' migration to Spain and their entry into the sex industry of that nation make it difficult to apply this term to the effects of their choices and travels. However, though these women's activities in their search for social 
mobility may not alter the collective social order, they do indeed confront concepts of prostitution and trafficking of women, which are currently hegemonic in Brazilian and in the international debate, and this, in turn, has conferred upon them an important measure of social agency.

The economic crisis that has affected Spain since 2009 has had consequences for the sex industry. A few years ago, sex workers could earn $4000 \mathrm{eu}-$ ros a month working in the street and up to 8000 euros in clubs. By 2011, sex workers and agents connected to prostitution agreed that they had lost some $60 \%$ of their incomes. Some club owners planned to close their venues and several sex workers were thinking about how to supplement their incomes with services they would have rejected in the past. The crisis is provoking displacements in their occupations and is having an effect that abolitionist policies had failed to produce, pushing sex workers towards other occupations and even stimulating the decision to return to their home countries.

Brazil is a major emerging economy. Governmental information, disseminated in the media, associates the growth of the Brazilian economy with the reduction of social inequalities, manifest in an increase in persons who left poverty to form the "new Brazilian middle class". ${ }^{29}$

In the new configuration of the world economy, Brazil might also attract fluxes of foreign sex workers. This, in fact, is one of the new concerns in the Brazilian debate over the 2014 World Cup. At the same time, Brazilians intending to perform sex work abroad might now prefer to leave Spain for other destinations. I hope that the insights gathered from the sex workers' experiences discussed here might contribute to problematizing the new panics about human trafficking connected to the fresh routes followed by migrants who intend to improve their lives.

\section{References}

Agustin, Laura. 2007. Sex at the Margins. Migration, Labour Markets and the Rescue Industry. London: Zed Books.

Assis, Glaucia. 2004. De Criciúma para o mundo: rearranjos familiares e de gênero nas vivências dos novos migrantes brasileiros. PHd Thesis. State University of

29 O Estado de S.Paulo, 4/05/2011 - "Plano de Dilma para erradicar pobreza tem 16 milhões de brasileiros como alvo". 


\section{Campinas.}

Barry, Kathleen. 1997. "Prostitution of Sexuality: a Cause for New International Human Rights", Journal of Loss and Trauma, 2 (1): 27-48.

Bernstein, Elizabeth. 2007. Temporarily Yours, Intimacy, Authenticity, and the Commerce of Sex. Chicago: The University of Chicago Press.

Blanchette, Thaddeus. 2008. "A Puta e o Estado: Prestígio Nacional e o Controle das Mulheres, 1918 e 2008" paper presented at the 26 Meeting of the Brazilian Anthropologist Association. Porto Seguro.

Blanchette, Thaddeus and Da Silva Ana Paula. 2012. "On bullshit and the trafficking of women:moral entrepreneurs and the invention of trafficking of persons in Brazil”, Dialectical Anthropology, 36:107-125, DOI 10.1007/s10624-012-9268-8

Butler, Judith. 1990. Gender Trouble, Feminism and the Subversion of Identity. New York: Routledge.

Cantarero, Joan. 2007: Los amos de la prostitución en España. Barcelona: Ediciones BSA.

Castilho, Ela. 2008 "A criminalização do tráfico de mulheres: proteção das mulheres ou reforço da violência de gênero?', Cadernos Pagu, 31:101-125.

Castilho, Ela. 2006. "A legislação penal brasileira sobre tráfico de pessoas e imigração ilegal/irregular frente aos Protocolos Adicionais à convenção de Palermo". Paper presented at the First Portuguese/Brazilian Seminar about Human Trafficking and Illegal Migration. Cascais.

Chame - Centro Humanitário de Apoio à Mulher. 1998. O que é que a Bahia tem. $O$ outro lado do turismo em Salvador. Salvador.

Chapkis, Wendy. 1997. Live Sex Acts: Women Performing Erotic Labour, London: Cassell.

DEPARTMENT of State, United States of America: Trafficking in Persons Report, http://www.state.gov/documents/organization/164452.pdf

Coletivo Mulher Vida. 1996. Sexo Turismo, o que agente não faz para realizar um sonho?. Olinda (Coord: Cecy Prestrello e Sandra Dias).

CORRÊA, Sonia e OLIVAR, José Miguel Nieto. 2010. The politics of prostitution in Brazil between "state neutrality" and "feminist troubles". Unpublished paper.

Doezema, Jo. 2001. "Ouch! Western Feminists "wounded attachment" to the “Third World prostitute". Feminist Review, 67: 16-38.

Doezema, Jo. 1998. "Forced to Choose. Beyond the Voluntary v. Forced 
Prostitution Dichotomy”, in K Kempadoo and J Doezema (eds) Global sex workers, Rights, Resistance, and Redefinition. London: Routledge.

Friedman, Ellen and Thorne, Barry. 1984: "Introduction to the Feminist Sexuality Debates", Signs, 10 (11): 102-135.

Garaizabal, Cristina. 2005. El estigma de la prostitución . Online. Available HTTP: 〈http:|| www.andainamulleres.org/artigresul_2.php?tiduo>

GOBIERNO DE ESPAÑA, Ministerio del Interior. 2007. Plan integral de luch contra la trata de seres humanos con fines de explotación sexual, Análisis de situación y plan de acción in: http://www.google.com.br/ search? sourceid=navclient Shl=pt-BR\&ie=UTF-8\&rlz=1T4DABR_pt-BRBR291BR 291\&q=plan+contra+la+trata+espa\%c3\%b1a

GONZALEZ, Lélia. 1982. "A mulher negra na sociedade brasileira (uma abordagem político-econômica)", in: Madel T. Luz: O Lugar da mulher: estudos sobre a condição feminina na sociedade atual. Rio de Janeiro: Edições Graal, 87-107.

Grupo da Vida. 2005. "Prostitutas, "traficadas" e pânicos morais: uma análise da produção de fatos em pesquisas sobre o "tráfico de seres humanos" Cadernos Pagu, 25: 153-185.

Kempadoo Kamala, Sanghera, I. and Pattanaik, B. (eds) 2005. Trafficking and Prostitution Reconsidered, New Perspectives on Migration, Sex Work and Human Rights, Boulder: Paradigm.

Kempadoo, Kamala. 1998. "Introduction”, in K. Kempadoo and J. Doezema (eds) Global sex workers, Rights, Resistance, and Redefinition, London: Routledge, 29-34.

Mestre, R. 2004. 'Las caras de la prostitución en el estado español: entre la ley de Extranjería y el Código Penal' in: R. Osborne (ed) Trabajador@as del sexo. Derechos, migraciones y tráfico en el siglo XXI, Barcelona: Bellaterra, 245-262.

Ministério da Justiça. 2007. Política Nacional de Enfrentamento ao tráfico de pessoas, Brasília: Secretaria Nacional de Justiça.

Ministério da Justiça. 2006. Pesquisas em Tráfico de Pessoas, parte 2, Relatório Indícios de tráfico de pessoas no universo de deportadas e não admitidas que regressam ao Brasil via o aeroporto de Guarulhos, Brasília.

Moraes, Maria. 1996 “Marxismo e Feminismo no Brasil” Primeira versão, 66, Campinas: Unicamp.

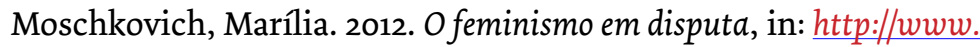
outraspalavras.net/2012/03/28/0-feminismo-em-disputal 
Munro, Valeria. 2008. "Of rights and Rhetoric: Discourses of Degradation and Exploitation in the Context of Sex Trafficking", Journal of Law and Society, 35 (2): 240-264.

NOBRE, Miriam e FARIA, Nalu. 2003. "Feminismo em movimento: temas e processos organizativos da Marcha Mundial das Mulheres no Fórum Social Mundial”. Revista Estudos Feministas, 11 (2): 36o, Florianópolis, julho-dezembro, 623-632.

Oliveira, Marina. 2008. "Sobre armadilhas e cascas de banana: uma análise crítica da administração de Justiça em temas associados a Direitos Humanos", Cadernos Pagu 31: 125-151.

Ong, Aiwa. 1999. Flexible Citizenship, The Cultural Logics of Transnationality, Durham: Duke University Press.

Oso Casas, Laura. 2005. Mullers inmigrantes y prostitución en Galicia (Migrant Women and Prostitution in Galicia). Available HTTP: <http:// www. andainamulleres.org/artigresul_2.php?tiduo>.

Pack, S. 2006. "How they see me and how I see them: the Ethnographic Self and the Personal self", Anthropological Quarterly, 79 (1): 105-122.

Piscitelli, Adriana. 2008. "Entre as “máfias” e a “ajuda”: a construção de conhecimento sobre tráfico de pessoas". Cadernos Pagu 31: 29-63.

Piscitelli, Adriana. 2011. "El debate feminista y la discusión sobre prostitución, reflexiones a partir de Brasil”. Paper presented at the $X$ Congreso Argentino de Antropologia Social, round table La antropología feminista hoy: desafíos teóricos y políticos en un mundo globalizado. PONS, Ignasi. 2003. Condicions de treball en la nova indústria de la prostitució: els clubs d'alterne. Barcelona, Universitat de Barcelona. Unpublished paper. PONS, Inaci, RODRÍGUEZ, Roser e VEGA, Sonia. 2002. Trabajo Sexual, Informe Cataluña, Departamento de Sociología i Análisis de las Organizaciones, Universidad de Barcelona.

SCOTT, Parry. 2011. Families, Nations and Generations in Women's International Migration. Vibrant, vol 8, n. 2, pp. 279- 306.

Secretaria Especial de Políticas Públicas para as mulheres. 2008. Workshop prostituição feminina, consolidado dos principais pontos debatidos. Brasília.

Secretaria Nacional de Justiça do Ministério da Justiça. 2010. Enfrentamento ao tráfico de pessoas, relatório do plano nacional, Brasília.

Senado Federal. Comissão Parlamentar de Inquérito. 2011. Criada por meio 
Relatório Parcial do Requerimento n226, de 2011, "para investigar o tráfico nacional e internacional de pessoas no Brasil, suas causas, conseqüências, rotas e responsáveis, no período 2003 e 2011, compreendido na vigência da convenção de Palermo". Presidente: Senadora Vanessa Grazziontin, Relatora: Senadora Marinor Brito. Brasília, dezembro.

SPRANDEL, Marcia Anita e MANSUR, Guilherme. 2010. "A temática do tráfico de pessoas no contexto brasileiro", REMHU/Revista Interdisciplinar da Mobilidade Humana, Ano XVIII, no 35: 155-169.

STENVOLL, Dag and O'CONNELL DAVIDSON, Julia. 2010. Human Rights, Victimhood and Consent. Social, legal and political dilemmas of victimhood. Introduction to the Workshop at the Rokkan Centre, Bergen, 1oth-12th of June 2010.

SURT. 2007. Obstáculos y dificultades de la reubicación de trabajadoras sexuales en el mercado laboral. Informe de investigación. (Redacción del Informe, Daniela Heim), Barcelona.

United Nations Office on Drugs and Crime. 2000. Protocol to prevent, suppress and Punish Trafficking in persons.

Viruell-Fuentes Edna. 2006. "My Heart is Always There”: The Transnational Practices of First-Generation Mexican Immigrant and Second-Generation Mexican American Women. Identities: Global Studies in Culture and Power, 13, pp 335-362

Women's Worldwide Link. 2012. Mujeres en los centros de internamiento de extranjeros (CIE) realidades entre rejas, in: http://www.womenslinkworldwide. org/wlw/new.php

\section{About the author}

Adriana Piscitelli is a feminist social anthropologist, Professor at the University of Campinas (Brazil), National Science Research Council Researcher and Senior Researcher of the Unicamp's Centre for Gender Studies - PAGU. During the last twelve years she has been engaged in studies focusing the transnational sex and marriage markets. She is author of: (2011) “Actuar la brasileñidad? Tránsitos a partir del mercado del sexo”. Revista Etnográfica, vol 15 (1): 5-29; (2008) "Looking for New Worlds: Brazilian Women as International Migrants", Signs: Journal of Women in Culture and Society, vol. 33: 784-793; (2008) “Tropical sex in a European country: Brazilian women's 
migration to Italy in the frame of international sex tourism". Estudos feministas, vol.4, special edition; (2007) "Shifting Boundaries: Sex and Money in the Northeast of Brazil”, Sexualities, Vol 10-4: 489-500.

Address: Rua Adalberto Maia, 99. Campinas, Cep 13076007 SP, e-mail: piscitelliadriana@gmail.com

Submitted February 2, 2012, approved April 4, 2012. 